\title{
A suppressive role of guanine nucleotide- binding protein subunit beta-4 inhibited by DNA methylation in the growth of anti- estrogen resistant breast cancer cells
}

Bo Wang ${ }^{1,2}$, Dongping $\mathrm{Li}^{1,2}$, Rocio Rodriguez-Juarez ${ }^{1}$, Allison Farfus ${ }^{1}$, Quinn Storozynsky ${ }^{1}$, Megan Malach', Emily Carpenter ${ }^{1}$, Jody Filkowski ${ }^{1}$, Anne E. Lykkesfeldt ${ }^{3}$ and Olga Kovalchuk ${ }^{1,4^{*}}$

\begin{abstract}
Background: Breast cancer is the most common malignancy in women worldwide. Although the endocrine therapy that targets estrogen receptor a (ERa) signaling has been well established as an effective adjuvant treatment for patients with ERa-positive breast cancers, long-term exposure may eventually lead to the development of acquired resistance to the anti-estrogen drugs, such as fulvestrant and tamoxifen. A better understanding of the mechanisms underlying antiestrogen resistance and identification of the key molecules involved may help in overcoming antiestrogen resistance in breast cancer.

Methods: The whole-genome gene expression and DNA methylation profilings were performed using fulvestrantresistant cell line $182^{R}-6$ and tamoxifen-resistant cell line TAM ${ }^{R}-1$ as a model system. In addition, GRT-PCR and Western blot analysis were performed to determine the levels of mRNA and protein molecules. MTT, apoptosis and cell cycle analyses were performed to examine the effect of either guanine nucleotide-binding protein beta-4 (GNB4) overexpression or knockdown on cell proliferation, apoptosis and cell cycle.

Results: Among 9 candidate genes, GNB4 was identified and validated by qRT-PCR as a potential target silenced by DNA methylation via DNA methyltransferase 3B (DNMT3B). We generated stable $182^{R}-6$ and $T_{A M}{ }^{R}-1$ cell lines that are constantly expressing GNB4 and determined the effect of the ectopic GNB4 on cell proliferation, cell cycle, and apoptosis of the antiestrogen-resistant cells in response to either fulvestrant or tamoxifen. Ectopic expression of GNB4 in two antiestrogen resistant cell lines significantly promoted cell growth and shortened cell cycle in the presence of either fulvestrant or tamoxifen. The ectopic GNB4 induced apoptosis in $182^{R}-6$ cells, whereas it inhibited apoptosis in $T_{A M}{ }^{R}-1$ cells. Many regulators controlling cell cycle and apoptosis were aberrantly expressed in two resistant cell lines in response to the enforced GNB4 expression, which may contribute to GNB4-mediated biologic and/or pathologic processes. Furthermore, knockdown of GNB4 decreased growth of both antiestrogen resistant and sensitive breast cancer cells.
\end{abstract}

Conclusion: GNB4 is important for growth of breast cancer cells and a potential target for treatment.

Keywords: Antiestrogen resistance, Breast cancer, DNA methylation, Fulvestrant, GNB4, Tamoxifen

\footnotetext{
* Correspondence: olga.kovalchuk@uleth.ca

${ }^{1}$ Department of Biological Sciences, University of Lethbridge, Lethbridge, $A B$,

Canada

${ }^{4}$ Hepler Hall, University of Lethbridge, 4401 University Drive, Lethbridge, AB

T1K 3M4, Canada

Full list of author information is available at the end of the article
}

(c) The Author(s). 2018 Open Access This article is distributed under the terms of the Creative Commons Attribution 4.0 International License (http://creativecommons.org/licenses/by/4.0/), which permits unrestricted use, distribution, and reproduction in any medium, provided you give appropriate credit to the original author(s) and the source, provide a link to the Creative Commons license, and indicate if changes were made. The Creative Commons Public Domain Dedication waiver (http://creativecommons.org/publicdomain/zero/1.0/) applies to the data made available in this article, unless otherwise stated. 


\section{Background}

Breast cancer is the most common malignancy found in women worldwide and the second leading cause of cancer-related deaths among North American women [1]. Globally, it is estimated that 1.67 million new cases were diagnosed, and 522,000 women died from this disease in 2012 (GLOBOCAN 2012). Approximately 60\% of these deaths were contributed by less developed countries. Although the exact etiology of breast cancer is currently unknown, the estrogen/estrogen-receptor (ER) signaling may play a crucial role in the development of this disease [2-5]. Furthermore, sustained estrogenic exposure may also increase the risk of breast, ovarian, and endometrial cancers [6].

Estrogen receptor alpha $(E R \alpha)$ and beta $(E R \beta)$, two ligand-inducible transcription factors, are members of the steroid/thyroid receptor superfamily that primarily mediate estrogen's biological function through binding [7]. ER $\alpha$ and ER $\beta$ are encoded by either ESR 1 or ESR2 genes that are composed of 595 and 530 amino acids, respectively. Both eventually form an N-terminal domain (NTD), a DNA-binding domain (DBD), and a ligandbinding domain (LBD) [8]. Sequence analysis indicates that $\mathrm{ER} \alpha$ and $\mathrm{ER} \beta$ display $~ 97 \%$ similarity in the $\mathrm{DBD}$ and $59 \%$ in the LBD, whereas they display only $16 \%$ similarity in the NTD [8]. This implicates a functional similarity and difference between these two ERs. For instance, once activated via estrogen binding, both dimerized ERs can either bind to the estrogen-response element (ERE) in the DNA or interplay with other transcription factors, such as AP1, Sp1, and NF-kB [9], eventually influencing the transcription of genes. However, ER $\alpha$ may predominantly bind to ERE elements [10], while ER $\beta$ may primarily interact with AP1 sites [11]. Furthermore, as demonstrated, ER $\alpha$ is a key player in promoting cell growth and proliferation $[12,13]$, whereas ER $\beta$ plays an important role in anti-proliferation, differentiation, and apoptosis in human malignancies, including breast cancer $[14,15]$.

Because ER $\alpha$ is expressed in $70 \%$ of breast cancers [16], and the proliferation of these ER $\alpha$-positive breast cancers is largely dependent on estrogen/ER $\alpha$ signaling [17], the endocrine therapy that targets estrogen/ER $\alpha$ signaling has been well established as an effective adjuvant treatment for patients with ER $\alpha$-positive breast cancers [18]. The endocrine-therapy agents that are currently used for ER $\alpha$-positive breast cancer include fulvestrant (also known as ICI 182,780 and faslodex, the ER downregulator that selectively downregulates and/or degrades ER $\alpha$ ), tamoxifen (the ER modulator that selectively antagonizes ER $\alpha$ function), and aromatase inhibitors (e.g. letrozole and anastrozole, which inhibit estrogen production by attenuating aromatase activity) [17, 19]. As an important adjuvant therapy, continuing 10-year tamoxifen treatment, when compared with 5-year exposure, has been shown to further reduce the risk of disease recurrence and mortality in a randomized trial of women with ER-positive breast cancers [20]. Unfortunately, long-term exposure may eventually lead to the development of acquired resistance to these drugs [21-23], which is a serious clinical problem in hormonal therapy. However, the underlying mechanisms are not completely understood.

In this study, we globally analyzed genomic DNA methylation, correlated with gene expression profiling, and identified GNB4 that was silenced by DNMT3B-mediated DNA methylation in both fulvestrant-resistant (MCF-7/ $\left.182^{\mathrm{R}}-6\right)$ and tamoxifen-resistant (MCF-7/TAM ${ }^{\mathrm{R}}-1$ ) breast cancer cell lines. Ectopic expression of GNB4 enhanced proliferation of MCF-7/182 $2^{\mathrm{R}}-6$ and MCF-7/TAM ${ }^{\mathrm{R}}-1$ cell lines in response to either fulvestrant or tamoxifen, while it shortened G2 and S phases in the cell cycle. We also noted that the ectopic expression of GNB4 induced apoptosis in the MCF-7/182 -6 cell line, whereas it attenuated the induction of apoptosis in the MCF-7/TAM ${ }^{\mathrm{R}}-1$ cell line. Cell-cycle and apoptosis regulators were aberrantly expressed in these cell lines in response to the ectopic GNB4 expression. In contrast, siRNA-mediated knockdown of GNB4 inhibited proliferation of two resistant cell lines in the presence of either fulvestrant or tamoxifen, and induced either $\mathrm{S}$ phase arrest or apoptosis. Our results provide novel insight into the role of GNB4 in the growth of both antiestrogen-resistant and sensitive breast cancer cells and may represent a target for treatment of breast cancer.

\section{Methods}

\section{Cell culture}

The MCF-7/S0.5 (S05), MCF-7/182 $2^{\mathrm{R}}-6$ (182 $\left.2^{\mathrm{R}}-6\right)$, and MCF-7/TAM ${ }^{\mathrm{R}}-1$ ( TAM $^{\mathrm{R}}$-1) cell sublines were developed by Dr. Anne Lykkesfeldt (Breast Cancer Group, Cell Death and Metabolism, Danish Cancer Society Research Center, DK-2100, Copenhagen, Denmark). ICI 182,780 (Faslodex, fulvestrant) and tamoxifen-resistant sublines, $182^{\mathrm{R}}-6$ and $\mathrm{TAM}^{\mathrm{R}}-1$, respectively, are derived from S05 as described elsewhere $[24,25]$. These cell lines were cultured in a DMEM/F-12 medium with $2.5 \mathrm{mM}$ L-Glutamine, without HEPES and phenol red (HyClone), and supplemented with $1 \%$ heat-inactivated fetal bovine serum (HyClone). Additionally, for $182^{\mathrm{R}}-6$ and $\mathrm{TAM}^{\mathrm{R}}-1$ sublines were regularly supplemented with $0.1 \mu \mathrm{M}$ ICI 182,780 and $1 \mu \mathrm{M}$ tamoxifen, respectively. Human mammary epithelial cells (HMEC) purchased from ThermoFisher Scientific (Cat\# A10565) were cultured in a HuMEC basal serum-free medium (ThermoFisher Scientific) containing HuMEC supplement (ThermoFisher Scientific), $100 \mathrm{IU} / \mathrm{mL}$ penicillin, and $100 \mathrm{mg} / \mathrm{mL}$ streptomycin. All cell lines were incubated at $37{ }^{\circ} \mathrm{C}$ in a humidified atmosphere of $5 \% \mathrm{CO}_{2}$. 


\section{Whole-genome gene expression profiling}

Total RNA was isolated from S05, $182^{\mathrm{R}}-6$, and $\mathrm{TAM}^{\mathrm{R}}-1$ cells using an Illustra RNAspin mini kit according to the manufacturer's instructions (GE Healthcare Life Sciences). Quantification, purity, and integrity of the RNA samples were measured using a NanoDrop 2000c spectrophotometer (Thermo Scientific) and an Agilent 2100 bioanalyzer (Santa Clara). RNA samples with RIN values of seven or higher were used for further analysis. Procedures for library preparation, hybridization, detection, BeadChip statistical analysis, and data processing have been described previously [19]. Heatmaps were generated by Dr. Yaroslav Ilnytskyy for genes that were differentially expressed between any of the groups (ANOVA type analysis with p.adjusted < 0.001) and for top 1000 most variable probes in DNA methylation.

\section{Whole-genome DNA methylation profiling}

DNA was extracted from cells using the DNeasy Blood and Tissue Kit (QIAGEN) and treated with DNase-free RNase (Sigma) according to the manufacturer's protocols. The collected DNA was bisulfite converted using the EZ DNA Methylation Kit (Zymo Research) according to the manufacturer's protocols. Methylation was measured using the Infinium assay on the Illumina platform. Data was collected from the $>27,000$ probes represented on the HM27 microarray. These probes contain CpG dinucleotides from selected loci throughout the genome. All steps were carried out according to the manufacturer's specifications and with Illumina-supplied reagents. Briefly, bisulfate-converted samples were amplified overnight, fragmented, and purified. The re-suspended samples were hybridized overnight to the microarray, which harboured millions of bead-bound 50-mer oligos. Each interrogated loci is represented by two bead types: a methylated type (" $\mathrm{C}$ " remains a " $\mathrm{C}$ ") and an unmethylated type ("C" become a "T"). Hybridized chips were washed to remove unbound and/or non-specific DNA fragments. The resulting oligo-sample hybrid was then extracted with a biotin-linked dideoxy cytosine and stained with streptavidin. The relative intensity of the unmethylated bead to the methylated bead for each allele provides a measure of relative methylation levels.

\section{Quantitative real-time RT-PCR (qRT-PCR)}

Total RNA, isolated from the indicated cell lines with TRIzol reagent (Invitrogen), was subjected to qRT-PCR using an iScript ${ }^{\mathrm{TM}}$ Select cDNA Synthesis kit and an SsoFast ${ }^{\mathrm{MT}}$ EvaGreen Supermix (Bio-Rad) with the primer set specifically to GNB4 (PrimePCR SYBR Green Assay, Bio-Rad) according to the manufacturer's instructions. Glyceraldehyde-3-phosphate dehydrogenase gene (GAPDH) was used as the internal control to standardize and test the RNA integrity with a sequence for the forward primer,
5'-GAA GGC TGG GGC TCA TTT-3', and for the reverse primer, 5'-CAG GAG GCA TTG CTG ATG AT-3' [26]. All qRT-PCR experiments were performed in triplicate, the data was analyzed using the comparative $\mathrm{Ct}$ method, and the results are shown as a fold induction of mRNA.

\section{Knockdown of DNMT3B}

$182^{\mathrm{R}}-6$ and $\mathrm{TAM}^{\mathrm{R}}-1$ cells grown to $80 \%$ confluency were transiently transfected with either $200 \mathrm{nM}$ Dnmt3b siRNA (Santa Cruz Biotechnologies) or 200 nM AllStars Negative Control siRNA (QIAGEN) using Lipofectamine 3000 (Invitrogen) according to the manufacturer's instructions. Seventy-two hours after transfection, the total RNA was isolated and subjected to qRT-PCR analysis using a primer set specifically to GNB4 (Bio-Rad) according to the manufacturer's instructions, and the whole cellular lysates were prepared and subjected to Western blot analysis using antibodies against DNMT3B and GNB4.

\section{Generation of GNB4 expression construct and GNB4 stable-expression cell lines}

The coding sequence of GNB4 was amplified by RT-PCR using total RNA isolated from HMEC. The PCR product was then cloned into a pGEM-T easy vector (Promega), released by digestion with EcoR I and $B a m \mathrm{H}$ I, and subcloned into a pEGFP-C1 vector (CloneTech) to generate pEGFP-GNB4. Sequence identity was confirmed by automatic sequencing. Primers used here for amplifying the GNB4 coding sequence are as follows: GNB4-F (5'-GAG AAT TCT ATG AGC GAA CTG GAA C-3') and GNB4-R (5'-GGG GAT CCA TTC CAG ATT CTA AG-3').

$182^{\mathrm{R}}-6$ and $\mathrm{TAM}^{\mathrm{R}}-1$ cells grown to $80 \%$ confluency were transfected with either pEGFP-GNB4 or pEGFP-C1 using Lipofectamine 3000 (Invitrogen). $24 \mathrm{~h}$ after transfection, G418 was added to final concentrations of $800 \mu \mathrm{g} / \mathrm{mL}$ and $400 \mu \mathrm{g} / \mathrm{mL}$ for $182^{\mathrm{R}}-6$ and $\mathrm{TAM}^{\mathrm{R}}-1$ cell lines, respectively, to kill the negative cells. The positive cells stably expressing either GFP or GFP-GNB4 were further selected with cell sorting (University of Calgary).

\section{MTT assay}

The MTT assay was performed as described previously [27]. Briefly, $3.0 \times 10^{3} 182^{\mathrm{R}}-6$ or $\mathrm{TAM}^{\mathrm{R}}-1$ or $\mathrm{S} 05$ cells transiently transfected with either $30 \mathrm{nM}$ GNB4 (Gß4) siRNA (Santa Cruz Biotechnology) or $30 \mathrm{nM}$ AllStars negative control siRNA (QIAGEN), or stably expressing either GFP or GFP-GNB4 were plated in 96-well plates. The 3-(4,5-Dimethylthiazol-2-yl)-2,5-diphenyl tetrazolium bromide (MTT) assays were carried out using a Cell Proliferation Kit I (Roche Diagnostics $\mathrm{GmbH}$ ) according to the manufacturer's instructions. The spectrophotometric 
absorbance of samples was measured at $595 \mathrm{~nm}$ using a microtiter plate reader (FLUOstar Omega).

\section{Cell cycle and apoptosis analyses}

$182^{\mathrm{R}}-6$ or $\mathrm{TAM}^{\mathrm{R}}-1$ cells stably expressing either GFP or GFP-GNB4 grown to $90 \%$ confluency were harvested for cell-cycle and apoptosis analyses that were performed with a BD FACSCanto ${ }^{\text {tw }}$ II Flow Cytometer (BD Biosciences) using a GFP-Certified Nuclear-ID Red Cell Cycle Analysis Kit (Enzo) and an Annexin V-Cy3 Apoptosis Kit Plus (BioVision) according to the manufacturer's instructions.

$182^{\mathrm{R}}-6$ or $\mathrm{TAM}^{\mathrm{R}}-1$ cells transiently transfected with either 30 nM GNB4 siRNA (Santa Cruz Biotechnology) or $30 \mathrm{nM}$ AllStars negative control siRNA (QIAGEN), $72 \mathrm{~h}$ (for $\mathrm{TAM}^{\mathrm{R}}-1$ line) or $96 \mathrm{~h}$ (for $182^{\mathrm{R}}-6$ line) after transfection, the cells were harvested for cell-cycle and apoptosis analyses that were performed with a BD FACSCanto $^{\text {Th }}$ II Flow Cytometer (BD Biosciences) using propidium iodide staining solution and FITC Annexin V Apoptosis Detection kit II (BD Biosciences) according to the manufacturer's instructions.

\section{Western blot analysis}

The indicated cells grown to $90 \%$ confluency were rinsed twice with ice-cold PBS and scraped off the plate in a radioimmunoprecipitation assay buffer (RIPA). We electrophoresed $30-100 \mu \mathrm{g}$ of protein per sample on $6 \%$ or $10 \%$ SDS-PAGE and electrophoretically transferred to a PVDF membrane (Amersham Hybond ${ }^{\mathrm{m}}-\mathrm{P}$, GE Healthcare) at $4{ }^{\circ} \mathrm{C}$ for $1.5 \mathrm{~h}$. Blots were incubated for one hour with $5 \%$ nonfat dry milk to block nonspecific binding sites and then incubated with polyclonal/monoclonal antibodies against BAX (BCL2-associated $\mathrm{X}$ protein), BCL2 (B-cell CLL/Lymphoma 2), DNMT3A (DNA methyltransferase 3A), GNB4, pAKT1/2/3 (phosphorylated AKT1/2/3) (Santa Cruz Biotechnology) or AKT1 (v-AKT murine thymoma viral oncogene homolog 1), DNMT1 (DNA methyltransferase 1), DNMT3B, p21 (Waf1/Cip1) (Abcam) or CDK2 (cyclin-dependent kinase 2), CDK6 (cyclin-dependent kinase 6), cyclin A2, cyclin D1, cyclin E1, ERK1/2 (extracellular signal-regulated kinase 1/2), MeCP2 (methyl-CpG-binding protein 2), and pERK1/2 (phosphorylated ERK1/2) (Cell Signaling Technology) at $4{ }^{\circ} \mathrm{C}$ overnight. Immunoreactivity was detected using a peroxidase-conjugated antibody and visualized by an ECL Plus Western Blotting Detection System (GE Healthcare). The blots were stripped before re-probing with antibody against actin (Santa Cruz Biotechnology).

\section{Statistical analysis}

The student's $t$-test was used to determine the statistical significance between groups in GNB4 expression, cell growth, cell cycle, and apoptosis. $p<0.05$ was considered significant.

\section{Results}

\section{Epigenetic silencing of GNB4 via DNMT3B-mediated DNA} methylation

To explore the contribution of DNA methylation to the development of the acquired resistance to endocrine therapy in breast cancer, using a fulvestrant-resistant $182^{\mathrm{R}}-6$ cell line, a tamoxifen-resistant $\mathrm{TAM}^{\mathrm{R}}-1$ cell line, and their parental line S05 as a model system, we performed wholegenome DNA methylation and gene-expression profilings. We identified 284 genes as common targets of DNA methylation in both $182^{\mathrm{R}}-6$ and $\mathrm{TAM}^{\mathrm{R}}-1$ cell lines (Fig. 1a and c). Differential expression in both antiestrogenresistant cell lines was evident in 210 genes (Fig. $1 \mathrm{~b}$ and d). We then correlated the expression of 210 genes with their DNA methylation status and identified nine downregulated genes, including annexin A6 (ANXA6), dual-specificity phosphatase 2 (DUSP2), ephrin B3 (EFNB3), guanine nucleotide-binding protein beta-4 (GNB4), methyltransferase-like 7A (METTL7A), $p 8$ (also known as candidate of metastasis 1, COM1), protease serine 23 (PRSS23), S100 calcium-binding protein A4 (S100A4), and tripartite motif-containing 4 (TRIM4). Their promoters were hypermethylated in both $182^{\mathrm{R}}-6$ and $\mathrm{TAM}^{\mathrm{R}}-1$ cell lines (Table 1), while only GNB4 was validated to be downregulated in both cell lines by qRT-PCR and Western blot analyses (Fig. 2a). Interestingly, Western blot analysis showed that DNMT3B was upregulated, while MeCP2 was downregulated in both cell lines. This implicates a common role of DNMT3B in both cell lines in GNB4 promoter hypermethylation, although DNMT1 may also play a role in the $\mathrm{TAM}^{\mathrm{R}}-1$ cell line (Fig. $2 \mathrm{~b}$ ). To test our hypothesis, DNMT3B was transiently knocked down using siRNA. Seventy-two hours after transfection, DNMT3B was downregulated by siRNA; as a result, GNB4 was upregulated at both mRNA and protein levels in $182^{\mathrm{R}}-6$ and $\mathrm{TAM}^{\mathrm{R}}-1$ cell lines (Fig. 2c and d); whereas, DNMT3B siRNA had no effect on the expression of both DNMT1 and DNMT3A (Fig. 2d). Our results suggest that GNB4 was epigenetically silenced in $182^{\mathrm{R}}-6$ and $\mathrm{TAM}^{\mathrm{R}}-1$ cell lines by DNA methylation via DNMT3B.

\section{Ectopic expression of GNB4 enhanced proliferation of antiestrogen-resistant breast cancer cells in the presence of antiestrogen drugs}

Since GNB4 was downregulated in antiestrogen-resistant breast cancer cells, we hypothesized that GNB4 may function as an "antidrug-resistant" gene that may restore the sensitivity of resistant cell lines to either fulvestrant or tamoxifen. To test our hypothesis by determining the role of GNB4 in the development of acquired fulvestrant and tamoxifen resistance in breast cancer, we generated GNB4 stable-expressing $182^{\mathrm{R}}-6$ and $\mathrm{TAM}^{\mathrm{R}}-1$ cell lines (Fig. 3a). Surprisingly, the MTT assay showed that the ectopic expression of GNB4 further enhanced drug-resistant 

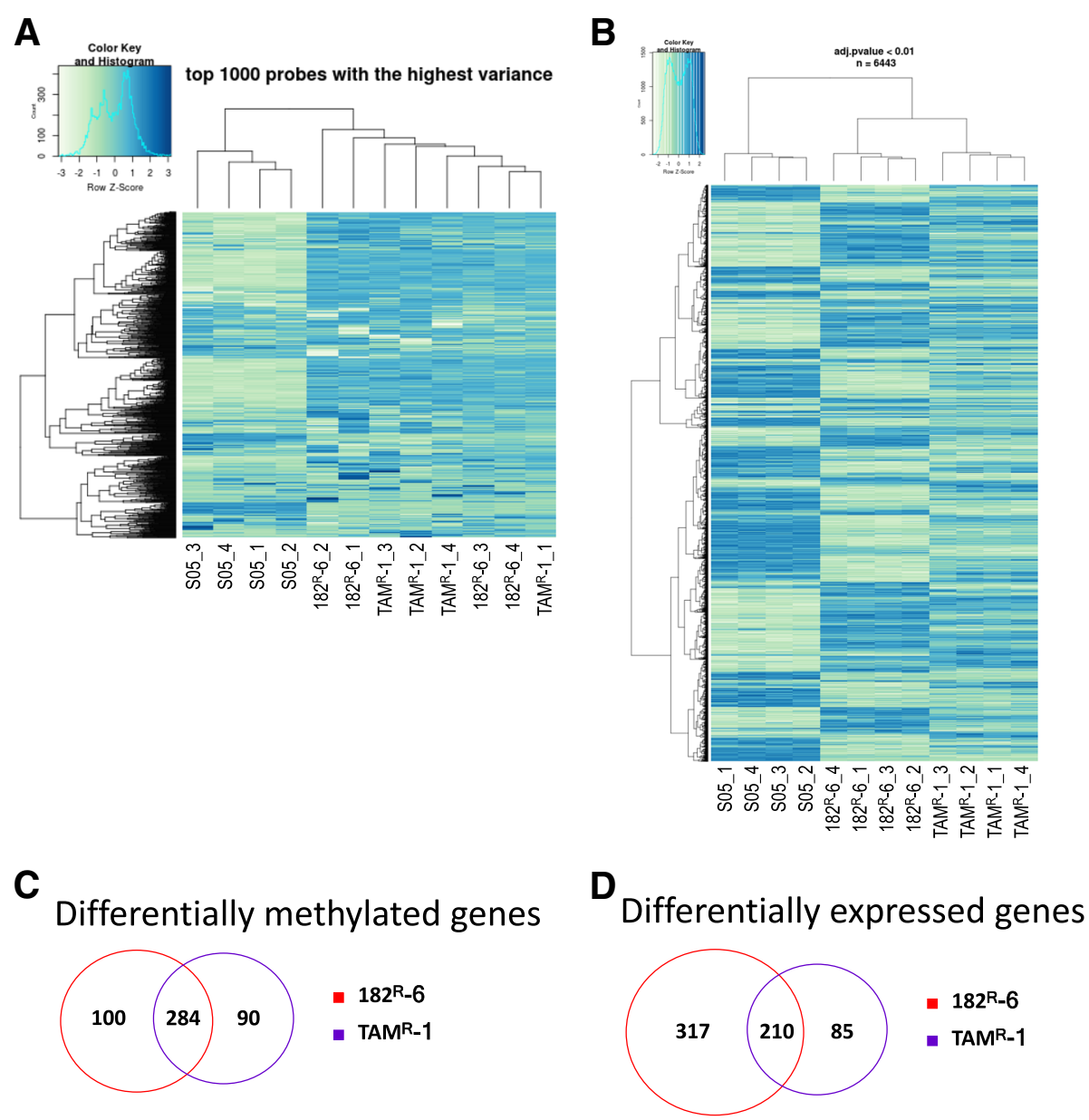

Fig. 1 Whole-genome DNA methylation and gene expression analyses. a, Heatmap of differentially methylated genes. DNA extracted from S05, $182^{R}-6$, and $T_{A M}^{R}-1$ cells was treated with DNase-free RNase and bisulfite converted; DNA methylation assay, data collection, and analysis were performed as described in "Methods". b, Heatmap of differentially expressed genes. Total RNA isolated from S05, 182 -6 , and TAMR -1 cells was subjected to gene expression profiling; the detailed procedures for library preparation, hybridization, detection, BeadChip statistical analysis, and data processing have been described previously [19]. $\mathbf{c}$ and $\mathbf{d}$, The number of differentially methylated genes (c) and differentially expressed genes (d) was presented with a Venn diagram

Table 1 Genes downregulated and their promoters hypermethylated

\begin{tabular}{llllllll}
\hline $182^{R}-6$ & & & & TAM $^{R}-1$ & & \\
\cline { 1 - 2 } \cline { 7 - 8 } Symbol & Expression & Methylation & & Symbol & Expression & Methylation \\
\hline ANXA6 & -1.84973 & 1.832057 & & ANXA6 & -1.67854 & 1.915985 \\
DUSP2 & -1.56577 & 2.003189 & & DUSP2 & -1.52014 & 2.115186 \\
EFNB3 & -2.55586 & 1.300826 & & EFNB3 & -1.73551 & 1.349243 \\
GNB4 & -1.50833 & 1.418815 & & GNB4 & -1.26312 & 1.129974 \\
METTL7A & -1.42021 & 1.223772 & & METTL7A & -1.01184 & 1.473379 \\
P8 & -1.55328 & 1.688645 & & P8 & -1.26429 & 1.672422 \\
PRSS23 & -1.17273 & 1.018398 & & PRSS23 & -2.00926 & 1.17323 \\
S100A4 & -1.8409 & 1.529188 & & S100A4 & -2.17128 & 1.478892 \\
TRIM4 & -1.57438 & 1.767231 & & TRIM4 & -1.08051 & 1.945837 \\
\hline
\end{tabular}

features of these cells by significantly promoting their proliferation $(p<0.05$, Fig. 3b and c), even though they were under treatment with either fulvestrant or tamoxifen. Interestingly, in the fulvestrant- and tamoxifen-free medium growth conditions, GNB4 overexpression had no effect on $182^{\mathrm{R}}-6$ cell growth (Additional file 1: Figure S1A), but suppressed $\mathrm{TAM}^{\mathrm{R}}-1$ cell proliferation (Additional file 1: Figure S1B). Our results suggest that GNB4 is a drugresistant gene in fulvestrant- and tamoxifen-resistant breast cancer cells.

\section{Ectopic expression of GNB4 altered cell cycle and apoptosis of antiestrogen-resistant breast cancer cells}

We next looked at the potential role of GNB4 in controlling the cell cycle and apoptosis of antiestrogen-resistant breast cancer cells. The cell-cycle analysis indicated that 
A
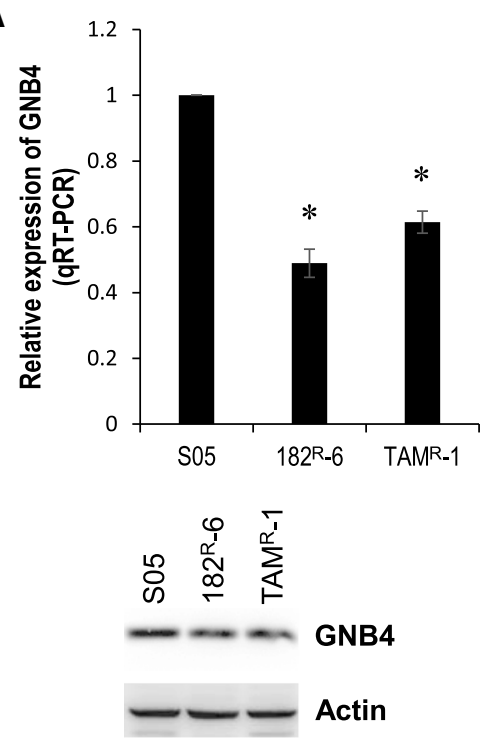

C

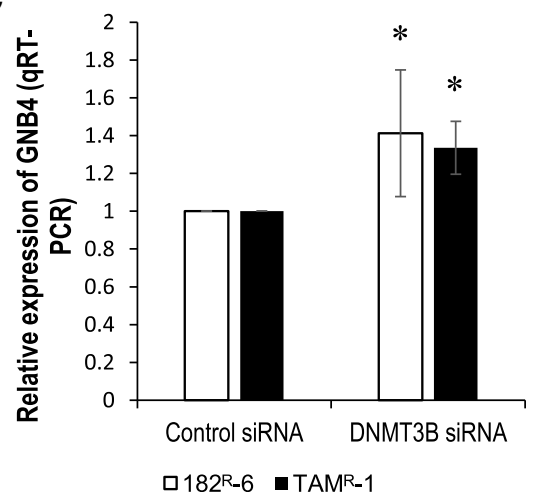

B

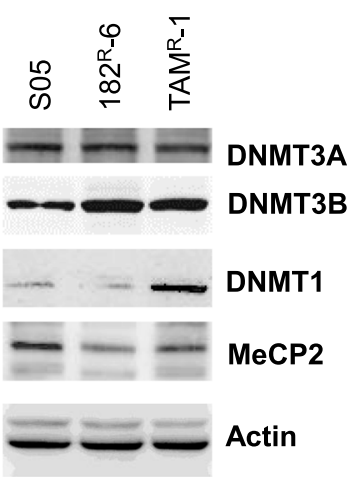

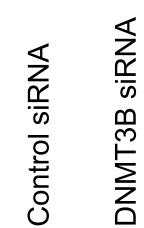
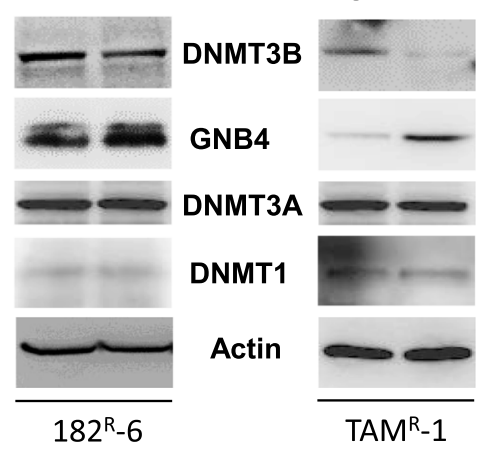

DNMT3A

DNMT1

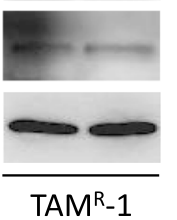

Fig. 2 Silencing of GNB4 in $182^{R}-6$ and TAM ${ }^{R}-1$ cells via DNMT3B. a, Total RNA isolated from S05, 182 ${ }^{R}-6$, and TAM ${ }^{R}-1$ cells was subjected to qRTPCR using a primer set specific to GNB4. Whole cellular lysate was prepared from S05, 182 ${ }^{R}-6$, and TAM ${ }^{R}-1$ cells, and Western blot analysis was performed using an antibody against GNB4. $\mathbf{b}$. Whole cellular lysate was prepared from S05, 182 -6 , and TAM -1 cells, and Western blot analysis was performed using antibodies against DNMT1, DNMT3A, DNMT3B, and MeCP2. c, $182^{R}-6$ and $T_{A M}^{R}-1$ cells were transiently transfected with either 200 nM DNMT3B siRNA or 200 nM negative control siRNA; $72 \mathrm{~h}$ after transfection, total RNA isolated from these cells was subjected to qRTPCR using a primer set specific to GNB4. d , Seventy-two hours after transfection, whole cellular lysate prepared from $182^{R}-6$ and TAM ${ }^{R}-1$ cells was transfected with either $200 \mathrm{nM}$ DNMT3B siRNA or $200 \mathrm{nM}$ negative control siRNA, and was subjected to Western blot analysis using antibodies against DNMT1, DNMT3A, DNMT3B and GNB4. Asterisk indicates $p<0.03$

the ectopic expression of GNB4 shortened S-phase in $182^{\mathrm{R}}-6$ cells and $\mathrm{G} 2$ in $\mathrm{TAM}^{\mathrm{R}}-1$ cells (Fig. $4 \mathrm{a}$ and b). The apoptosis analysis showed that the enforced expression of GNB4 induced apoptosis of the $182^{\mathrm{R}}-6$ cells, whereas it completely attenuated the induction of apoptosis in the $\mathrm{TAM}^{\mathrm{R}}-1$ cells (Fig. $4 \mathrm{c}$ and d).

To understand the mechanism underlying the GNB4mediated alterations in proliferation, cell cycle, and apoptosis, we determined the expression of cell cycle and apoptosis regulators in $182^{\mathrm{R}}-6$ and $\mathrm{TAM}^{\mathrm{R}}-1$ cells in response to a GNB4 expression. The Western blot analysis showed that cyclin A2 was downregulated, while CDK6 was upregulated in $182^{\mathrm{R}}-6$ and $\mathrm{TAM}^{\mathrm{R}}-1$ cells in response to the ectopic expression of GNB4 (Fig. 5a).
Interestingly, GNB4 caused an induction in genes, including those of cyclin D1 and E, CDK2, BAX, and phosphorylated Akt $1 / 2 / 3$ in $182^{\mathrm{R}}-6$ cells, whereas it attenuated the expression of these gene in $\mathrm{TAM}^{\mathrm{R}}-1$ cells (Fig. $5 \mathrm{a}$ and b). Although BCL2 and phosphorylated ERK1/2 were elevated in $182^{\mathrm{R}}-6$ by GNB4, they had no effect in $\mathrm{TAM}^{\mathrm{R}}-1$ cells (Fig. 5b). Additionally, GNB4 had no effect on p21 expression in both cell lines (Fig. 5a).

Knockdown of GNB4 with siRNA suppressed proliferation and induced apoptosis and cell cycle arrest of antiestrogen-resistant breast cancer cells

To further confirm the role of GNB4 in the control of cell proliferation, cell cycle and apoptosis in antiestrogen 
A

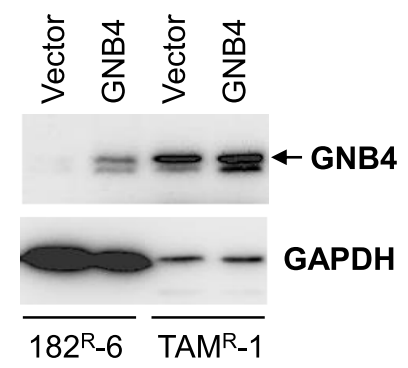

B
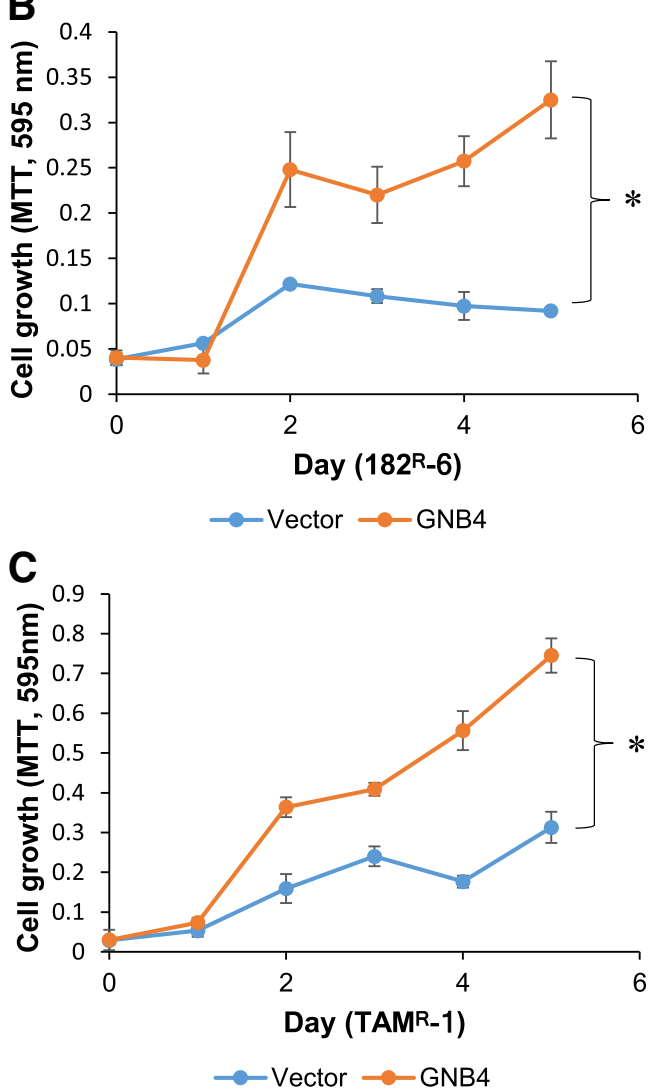

Fig. 3 The ectopic expression of GNB4 enhances the proliferation of antiestrogen-resistant breast cancer cells. $\mathbf{a}, 182^{R}-6$ and TAM ${ }^{R}-1$ cells were transfected with either pEGFP-GNB4 or pEGFP-C1; after G418 selection, whole cellular lysate prepared from the positive cells was subjected to Western blot analysis using an antibody against GNB4. b and $\mathbf{c}$, MTT assay was performed using $182^{R}-6$ (b) and TAM ${ }^{R}-1$ (c) cells stably expressing GNB4 or GFP as described in "Methods". Asterisk indicates $p<0.05$

resistant $182^{\mathrm{R}}-6$ and $\mathrm{TAM}^{\mathrm{R}}-1$ cells, we then knocked down GNB4 using siRNA and measured the effect on cell proliferation, cell cycle and apoptosis. Western blot analysis showed that $72 \mathrm{~h}$ after transfection, the expression of GNB4 was attenuated in $\mathrm{TAM}^{\mathrm{R}}-1$ cell line (Additional file 2: Figure S2), while had no effect in $182^{\mathrm{R}}-6$ cell line. However, at $96 \mathrm{~h}$ after transfection, the expression of GNB4 was also reduced in $182^{\mathrm{R}}$ - 6 cell line by GNB4 siRNA (Additional file 3: Figure S4). As expected, knockdown of GNB4 suppressed proliferation of $182^{\mathrm{R}}-6$ and $\mathrm{TAM}^{\mathrm{R}}-1$ cells in response to either fulvestrant or tamoxifen (Fig. 6a and b). Interestingly, Knockdown of GNB4 induced significantly apoptosis in $\mathrm{TAM}^{\mathrm{R}}-1$ cells (Fig. 6b, middle panel), while had no effect on that in $182^{\mathrm{R}}-6$ cells (Fig. 6a, middle panel). Furthermore, knockdown of GNB4 induced S-phase arrest in $182^{\mathrm{R}}-6$ cells (Fig. 6a, right panel), whereas had no effect on that in $\mathrm{TAM}^{\mathrm{R}}-1$ cells (Fig. 6b, right panel). Moreover, knockdown of GNB4 also inhibited proliferation of the parental S05 cells in the absence of antiestrogen drugs (Additional file 4: Figure S3), in addition to a role in drug resistance, may also implicating a role in the development of breast cancer.

\section{Discussion}

Although the well-established and effective endocrine therapy has provided millions of women with ER+ breast cancer with targeted treatment option [20, 23], most patients with metastatic disease would unfortunately and inevitably develop resistance to the drugs [28, 29], which has become a major clinical challenge in the treatment of this disease. As demonstrated, the reactivation (reestablishment) of ER and growth-factor signaling through crosstalk has been proposed as a primary mechanism for the development of antiestrogen resistance. A central role of upregulated EGFR/ErbB and the sustained activation of the EGFR/ErbB/ERK signaling pathway has been strongly indicated in the maintenance of antiestrogen-resistant breast cancer cell growth [30-32]. Although ER $\alpha$ is downregulated in tamoxifen-resistant breast cancer cell lines, the receptor is highly activated (phosphorylated) [32]. 
A
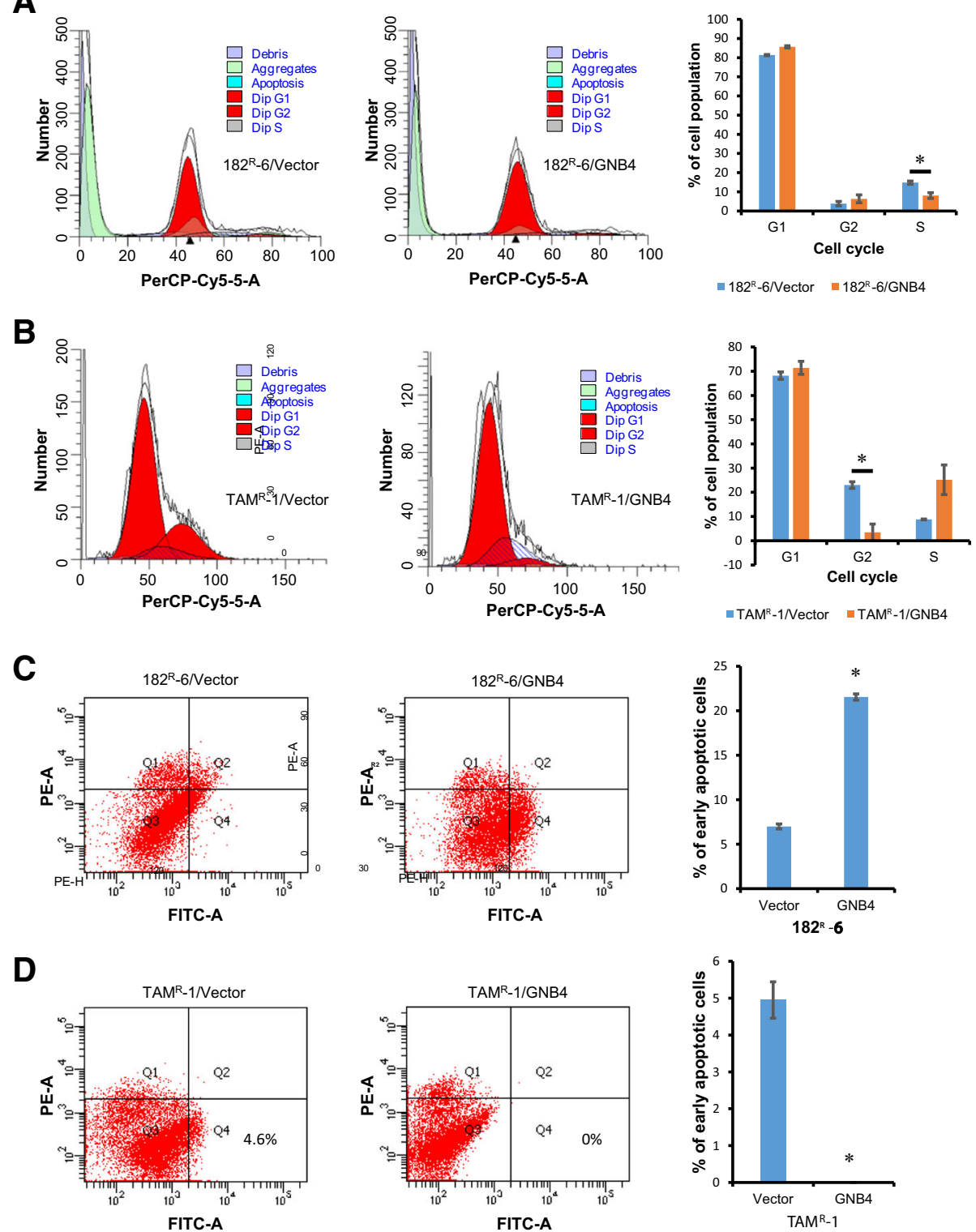

Fig. 4 The ectopic expression of GNB4 causes alterations in cell cycle and apoptosis. a and $\mathbf{b}, 182^{R}-6$ and TAM ${ }^{R}-1$ cells stably expressing GNB4 or GFP grown to 90\% confluency were subjected to cell cycle analysis using a GFP-Certified Nuclear-ID Red Cell Cycle Analysis Kit according to the manufacturer's instructions. $\mathbf{c}$ and $\mathbf{d}, 182^{R}-6$ and TAM -1 cells stably expressing GNB4 or GFP grown to $90 \%$ confluency were subjected to apoptosis analysis using an Annexin V-Cy3 Apoptosis Kit Plus according to the manufacturer's instructions. Asterisk indicates $p<0.05$

Importantly, the activated ER has been shown to promote the expression of insulin-like growth factor II (IGF2) in tamoxifen-resistant cell lines, resulting in the reactivation of insulin-like growth factor 1 receptor (IGF1R) signaling that activates EGFR via c-src-dependent phosphorylation [33]. Interestingly, the activated IGF2/IGF1R signaling may therefore in turn contribute to the phosphorylation of ER in tamoxifen-resistant cell lines [33], hence forming a positive-feedback proliferation loop. In addition, changes in the sensitivity of antiestrogen-resistant breast cancer cells to estradiol (E2) may also play a pivotal role in the development of antiestrogen resistance. Several lines of evidence have demonstrated that long-term estrogen deprivation (LTED) enhances the sensitivity of breast cancer cells to low levels of E2 ( 10,000-fold reduction) [34-36]. The biological effect induced by E2 hypersensitivity, such as proliferation, was also mediated by the activation (phosphorylation) of ER and ERK1/2 (extracellular signalregulated kinase 1/2) signalings. More recently, several studies highlighted a key role of protein kinases in the 
A
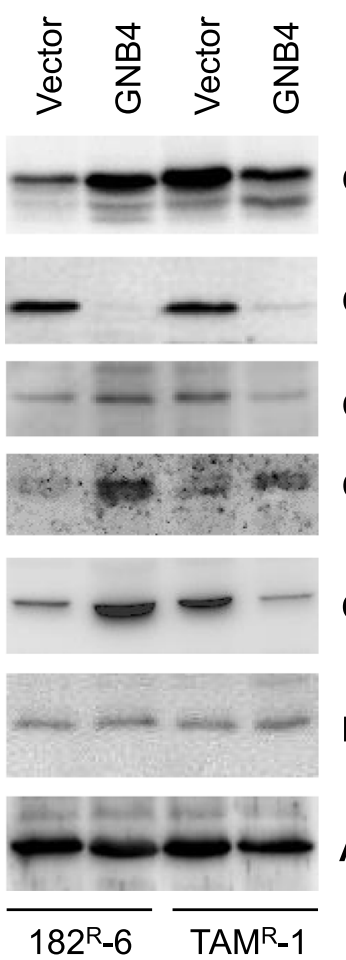

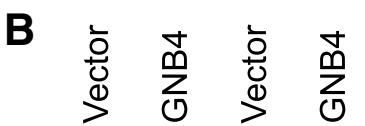

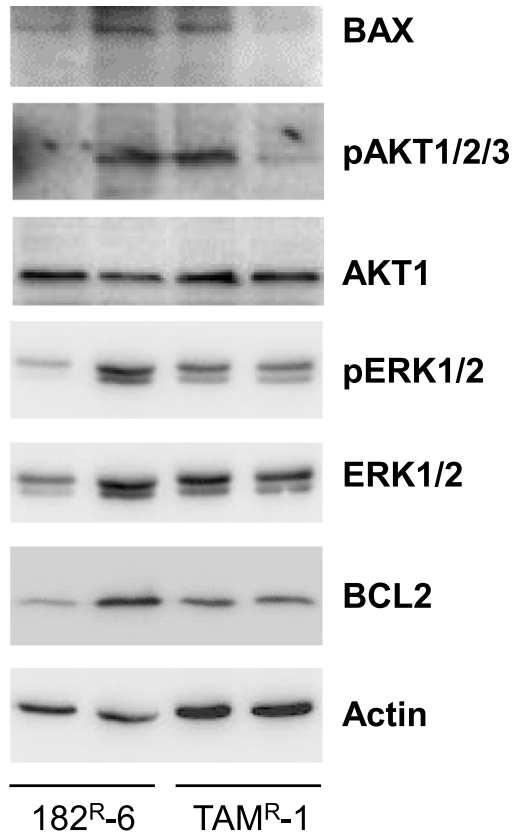

Fig. 5 Changes of cell cycle and apoptosis regulators in response to enforced GNB4 expression. $\mathbf{a}$ and $\mathbf{b}$, Whole cellular lysate prepared from $182^{R}-6$ and TAM $^{R}-1$ cells stably expressing GNB4 or GFP was subjected to Western blot analysis using the indicated antibodies

A

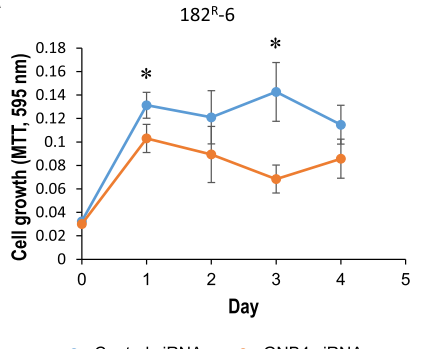

$\rightarrow$ Control siRNA $\rightarrow$ GNB4 siRNA

B

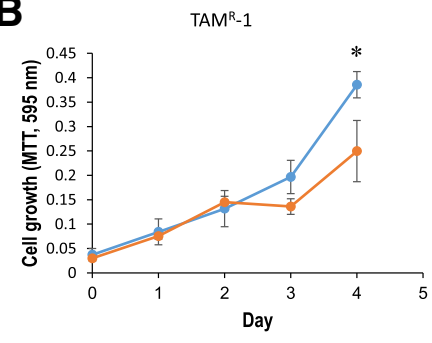

$\rightarrow$ Control siRNA $\rightarrow$ GNB4 siRNA
$182^{\mathrm{R}-6}$
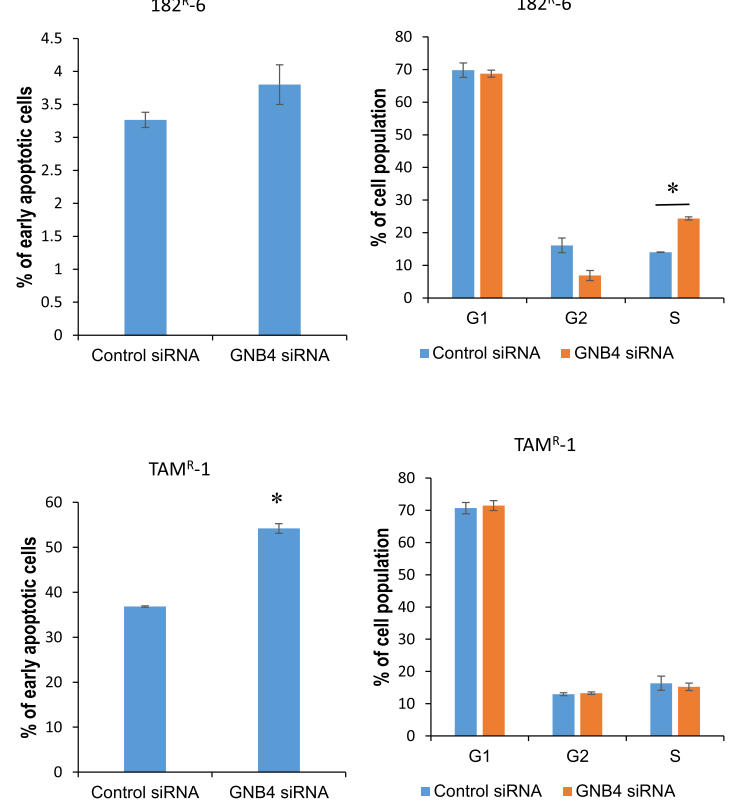

TAM $^{R}-1$

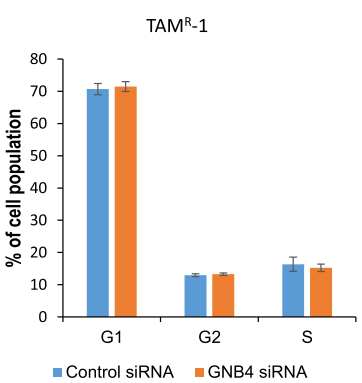

Fig. 6 Knockdown of GNB4 inhibits proliferation and induces cell cycle arrest and apoptosis. $\mathbf{a}$ and $\mathbf{b}, 182^{\mathrm{R}}-6$ and TAM ${ }^{\mathrm{R}}-1$ cells grown to $80 \%$ confluency were transiently transfected with either $30 \mathrm{nM}$ GNB4 siRNA or $30 \mathrm{nM}$ negative control siRNA; $24 \mathrm{~h}$ after transfection, the cells were replated in 96-well plate; the MTT assay was performed as described in "Methods"; $72 \mathrm{~h}\left(\operatorname{TAM}^{\mathrm{R}}-1\right)$ or $96 \mathrm{~h}\left(182^{\mathrm{R}}-6\right)$ after transfection, the cells were harvested for cell cycle and apoptosis analyses. Asterisk indicates $p<0.05$ 
development of antiestrogen resistance, such as tyrosine kinase FYN and aurora kinase A [37, 38]. Interestingly, the tamoxifen-resistant breast cancer cells may derive from cancer stem-like cells [39].

To our knowledge, this study has revealed, for the first time, that GNB4 was epigenetically silenced in antiestrogenresistant breast cancer cells, and it has highlighted an important role of GNB4 in the growth of antiestrogen resistant breast cancer cells. Heterotrimeric $\mathrm{G}$ proteins which are composed of an alpha subunit, a beta subunit (e.g. GNB4), and a gamma subunit function as molecular switches that play a crucial role in signal transduction from a cell surface receptor to internal effectors in a $G$ protein-coupled receptor (GPCR) pathway [40]. Although the GPCR signaling pathway has been extensively studied, very little is known about GNB4. However, since the GPCR pathway plays a pivotal role in many biologic and pathologic processes, including tumorigenesis, it may also reflect a role of GNB4 in these processes. Evidence has demonstrated that GNB-isoforms are essential for chemokine-induced GPCR downstream signaling [41]. GNB4 may be one of the key genes that cause Charcot-Marie-Tooth disease, a heterogeneous group of the inherited neuropathies [42, 43]. GNB4 has also been linked to cancer. Haplotypes of GNB4 intron-1 have been shown to be associated with the survival rate of patients with colorectal and urothelial bladder carcinomas [44, 45]. We showed here that GNB4 was downregulated in both fulvestrant- and tamoxifen-resistant breast cancer cell lines, and that this was attributed to DNMT3B-mediated DNA methylation, because knockdown of DNMT3B by siRNA significantly elevated the expression of GNB4 at both mRNA and protein levels (Fig. 2). GNB4 has been reported to be downregulated in progressive breast cancer due to the acquired tamoxifen resistance [46], which is consistent with our results. Importantly, we found that the ectopic expression of GNB4 remarkably promoted the proliferation of antiestrogenresistant breast cancer cells in response to antiestrogen drugs (Fig. 3). We also noted that the enforced expression of GNB4 caused cell cycles G2 and S to undergo phase acceleration (Fig. 4a and b), which may contribute to the GNB4-mediated proliferation of antiestrogen-resistant cells (Fig. 3b and c). Interestingly, the ectopic expression of GNB4 completely abolished apoptosis in tamoxifen-resistant $\mathrm{TAM}^{\mathrm{R}}-1$ cells, while it significantly induced apoptosis in fulvestrant-resistant $182^{\mathrm{R}}-6$ cells (Fig. $4 \mathrm{c}$ and d). However, the dramatic effects of GNB4 on apoptosis in both cell lines may all contribute to GNB4-mediated cellular proliferation (Fig. 3b and c). Recently, several interesting studies have indicated that apoptotic cells could promote the proliferation of surrounding cells (apoptosis-induced proliferation) due to the mitogenic signals released by the apoptotic cells [47-49]. siRNA-mediated GNB4 knockdown, however, suppressed proliferation of $182^{\mathrm{R}}-6$ and $\mathrm{TAM}^{\mathrm{R}}-1$ cells in the presence of antiestrogen drugs, and induced S-phase arrest of $182^{\mathrm{R}}-6$ cells and apoptosis of $\mathrm{TAM}^{\mathrm{R}}-1$ cells (Fig. $6 \mathrm{a}$ and $\mathrm{b}$ ), further validating a crucial role of GNB4 in the development of antiestrogen resistance of breast cancer cells. GNB4 siRNA had no effect on GNB4 expression in $182^{\mathrm{R}}-6$ cells at $72 \mathrm{~h}$ after transfection (Additional file 2: Figure S2), may reflect a longer half-life time of GNB4 in this cell line, since in another independent experiment, GNB4 was noted to be downregulated at $96 \mathrm{~h}$ after transfection (Additional file 3: Figure $\mathrm{S} 4 \mathrm{~A}$ and $\mathrm{B}$ ).

GNB4 is a key component of heterotrimeric G proteins, which play an essential role in the transduction of GPCR-mediated signaling. Because of the crucial role of GPCR in the activation of AKT ( $\mathrm{v}$-AKT murine thymoma viral oncogene homolog) and ERK1/2 pathways [50, 51], an increase in phosphorylated AKT and/or phosphorylated ERK1/2 was expected to be seen in antiestrogen-resistant cells in response to the ectopic GNB4 expression. As expected, the phosphorylated AKT and phosphorylated ERK1/2 were elevated in $182^{\mathrm{R}}-6$ cells in response to the GNB4 expression (Fig. 5b). This may contribute to GNB4-mediated cellular proliferation (Fig. 3b). However, the enforced expression of GNB4 caused a reduction in the phosphorylated AKT and had no effect on the phosphorylated ERK1/2 in $\mathrm{TAM}^{\mathrm{R}}-1$ cells (Fig. 5b). The mechanism involved is unclear. It may be interesting to look at the crosstalk with other pathways, such as ER. Importantly, the GNB4-induced upregulation of BAX in $182^{\mathrm{R}}-6$ cells and the downregulation in $\mathrm{TAM}^{\mathrm{R}}-1$ cells may contribute to GNB4's effect on apoptosis in these cells (Fig. 5b and Fig. 4c and d). We also noted that GNB4 caused an induction in BCL2 in $182^{\mathrm{R}}-6$ cells, while it had no effect in $\mathrm{TAM}^{\mathrm{R}}-1$ cells (Fig. $5 \mathrm{~b}$ ), implicating that the functional effect of GNB4 on apoptosis in $182^{\mathrm{R}}-6$ cells may be due to the balance between proapoptotic (BAX) and antiapoptotic (BCL2) proteins.

Cyclins and cyclin-dependent kinases control cell-cycle progression and transitions. Cyclin A interacts with cyclindependent kinase 2 (CDK2) or CDK1 to form a complex that governs the $\mathrm{S}$ phase of the cell cycle [52]. Cyclin D interacts with CDK4 or CDK6 to form a complex that controls the G1 phase of the cell cycle [49]. However, in a complex with CDK2, cyclin E controls the S-phase progression and G1-S transition [52, 53]. The results we presented here showed that cyclin E and CDK2 were upregulated in $182^{\mathrm{R}}-6$ cells in response to GNB4 (Fig. 5a), which may contribute to the shortened $\mathrm{S}$ phase (Fig. 4a). The ectopic GNB4, however, attenuated the expression of CDK2 and cyclin A and E in TAM ${ }^{R}-1$ cells (Fig. 5a), which may contribute to the S-phase arrest (Fig. 4a). Although the ectopic GNB4 caused a profound induction in both cyclin D1 and CDK6 in $182^{\mathrm{R}}-6$ cells (Fig. 5a), this induction had no effect on the G1 phase of the cell cycle 
(Fig. 4a). The GNB4-induced upregulation of CDK6 and downregulation of cyclin D1 had no effect on the G1 phase of TAM ${ }^{\mathrm{R}}-1$ cells (Fig. 5a and Fig. 4b). We also noted that the ectopic GNB4 had no effect on the expression of p21, an inhibitor of cyclin D/CDK6 and cyclin E/CDK2 complexes [54]. However, the mechanism underlying the shortened GNB4-induced G2 phase of the cell cycle in $\mathrm{TAM}^{\mathrm{R}}-1$ cells is still unclear. Although we did not measure the expression of $\mathrm{CDC} 25$ and speedy/ringo $\mathrm{C}$ in these cells, it has been demonstrated that these two molecules play an important role in controlling G2-phase progression $[55,56]$.

\section{Conclusion}

In summary, although the observed reduced level of GNB4 in the two antiestrogen resistant cell lines is not the underlying cause of antiestrogen resistance, GNB4 is important for growth of both antiestrogen resistant and antiestrogen sensitive breast cancer cells and thereby a target for treatment of breast cancer.

\section{Additional files}

Additional file 1: Figure S1. Effect of GNB4 overexpression on cell growth of $182^{R}-6$ and $T_{A M}{ }^{R}-1$ cell lines (no drug treatment). A and B, MTT assay was performed using $182^{R}-6$ (a) and $\operatorname{TAM}^{R}-1$ (b) cells stably expressing GFP or GNB4 as described in "Methods", using fulvestrant- and tamoxifen-free medium. Asterisk indicates $p<0.05$. (PPTX $42 \mathrm{~kb}$ )

Additional file 2: Figure S2. Knockdown of GNB4 in $T_{A M}^{R}-1$ and $182^{R}-6$ cells using siRNA. $182^{R}-6$ and $T_{A M}^{R}-1$ cells grown to $80 \%$ confluency were transiently transfected with either $30 \mathrm{nM}$ GNB4 siRNA or $30 \mathrm{nM}$ negative control siRNA; at $72 \mathrm{~h}$ after transfection, whole cellular lysates were prepared and subjected to Western blot analysis using antibody against GNB4. (PPTX $508 \mathrm{~kb}$ )

Additional file 3: Figure S4. siRNA-mediated knockdown of GNB4 in $T_{A M}^{R}-1$ and $182^{R}-6$ cells. $A, 182^{R}-6$ and $T^{2} M^{R}-1$ cells grown to $80 \%$ confluency were transiently transfected with either $30 \mathrm{nM}$ GNB4 siRNA or $40 \mathrm{nM}$ negative control siRNA; At 72 and $96 \mathrm{~h}$ after transfection, whole cellular lysates were prepared and subjected to Western blot analysis using antibody against GNB4. B, a relative densitometry (GNB4/Actin) was performed to further validate the GNB4 expression in $182^{R}-6$ cell line $96 \mathrm{~h}$ after transfection, using ImageJ software. Asterisk indicates $p<0.05$. (PPTX $49 \mathrm{~kb}$ )

Additional file 4: Figure S3. Knockdown of GNB4 using siRNA suppresses proliferation of parental S05 cells. S05 cells grown to 80\% confluency were transiently transfected with either $30 \mathrm{nM}$ GNB4 siRNA or $30 \mathrm{nM}$ negative control siRNA; at $24 \mathrm{~h}$ after transfection, the cells were replated in 96-well plate, MTT assay was performed as described in "Methods". Asterisk indicates $p<0.05$. (PPTX $37 \mathrm{~kb}$ )

\footnotetext{
Abbreviations

AKT1: V-AKT murine thymoma viral oncogene homolog 1; BAX: BCL2-associated X protein; BCL2: B-cell CLL/Lymphoma 2; CDK2: cyclin-dependent kinase 2; CDK6: cyclin-dependent kinase 6; DBD: DNA-binding domain; DNMT1: DNA methyltransferase 1; DNMT3A: DNA methyltransferase 3A; DNMT3B: DNA methyltransferase 3B; ER: Estrogen receptor; ERK1/2: Extracellular signal-regulated kinase 1/2; GAPDH: Glyceraldehyde-3-phosphate dehydrogenase gene; GNB4: Guanine nucleotide-binding protein beta-4; HMEC: Human mammary epithelial cells; LBD: Ligand-binding domain; MeCP2: Methyl-CpG-binding protein 2; MTT: The 3-(4,5-Dimethylthiazol-2-yl)-2,5-diphenyl tetrazolium bromide; NTD: N-terminal domain; GRT-PCR: Quantitative real-time RT-PCR; siRNA: Small interfering RNA
}

\section{Acknowledgements}

We thank Ms. Rommy Rodriguez-Juarez, and Dr. Andrey Golubov and Dr. Yaroslav Innytskyy for their technical and bioinformatics support. Ms. Megan Malach was a recipient of the Al-HS Summer Studentship. Ms. Emily Carpenter was a recipient of the NSERC Summer Research Award.

\section{Funding}

Study was supported by the Alberta Cancer Foundation and the CIHR grants to Dr. Olga Kovalchuk. The funding body did not have any influence on the design of the study, data collection, analysis or interpretation or writing the manuscript

\section{Availability of data and materials}

The datasets generated and/or analysed during the current study are not publicly available due to the ongoing IP-protection issues but are available from the corresponding author on reasonable request.

\section{Authors' contributions}

$B W, J F, A E L$ and OK conceived and designed the study; BW, DL, RRJ, AF, QS, $M M, E C$ and JF performed the experiments and collected data; BW, DL and JF analyzed and interpreted data; BW, JF, AEL and OK drafted and revised the manuscript; BW and OK supervised the study; All authors read and approved the final manuscript.

Ethics approval and consent to participate Not applicable.

\section{Consent for publication}

All authors consented for publication of the manuscript in the journal of BMC Cancer.

\section{Competing interests}

The authors declare that they have no competing interests.

\section{Publisher's Note}

Springer Nature remains neutral with regard to jurisdictional claims in published maps and institutional affiliations.

\section{Author details}

'Department of Biological Sciences, University of Lethbridge, Lethbridge, $A B$, Canada. ${ }^{2}$ Department of Biochemistry, Qiqihar Medical University, Qiqihar, People's Republic of China. ${ }^{3}$ Breast Cancer Group, Cell Death and Metabolism, Danish Cancer Society Research Center, Strandboulevarden, Copenhagen, Denmark. ${ }^{4}$ Hepler Hall, University of Lethbridge, 4401 University Drive, Lethbridge, AB T1K 3M4, Canada.

Received: 21 November 2017 Accepted: 31 July 2018 Published online: 13 August 2018

\section{References}

1. Schairer C, Mink PJ, Carroll L, Devesa SS. Probabilities of death from breast cancer and other causes among female breast cancer patients. J Natl Cancer Inst. 2004:96(17):1311-21.

2. Russo $H$, Russo J. Role of hormones in mammary cancer initiation and progression. J Mammary Gland Biol Neoplasia. 1998;3(1):49-61.

3. Sommer S, Fuqua SA. Estrogen receptor and breast cancer. Semin Cancer Biol. 2001:11(5):339-52.

4. Keshamouni VG, Mattingly RR, Reddy KB. Mechanism of 17-beta-estradiolinduced Erk1/2 activation in breast cancer cells. A role for HER2 AND PKC-delta. J Biol Chem. 2002;277(25):22558-65.

5. Kovalchuk O, Tryndyak VP, Montgomery B, Boyko A, Kutanzi K, Zemp F, et al. Estrogen-induced rat breast carcinogenesis is characterized by alterations in DNA methylation, histone modifications and aberrant microRNA expression. Cell Cycle. 2007:6(16):2010-8.

6. Zhou W, Slingerland JM. Links between oestrogen receptor activation and proteolysis: relevance to hormone-regulated cancer therapy. Nat Rev Cancer. 2014;14(1):26-38

7. Tsai MJ, O'Malley BW. Molecular mechanisms of action of steroid/thyroid receptor superfamily members. Annu Rev Biochem. 1994;63:451-86. 
8. Dey P, Barros RP, Warner M, Strom A, Gustafsson JA. Insight into the mechanisms of action of estrogen receptor beta in the breast, prostate, colon, and CNS. J Mol Endocrinol. 2013;51(3):T61-74.

9. Webb P, Nguyen P, Valentine C, Lopez GN, Kwok GR, Mclnerney E, et al. The estrogen receptor enhances AP-1 activity by two distinct mechanisms with different requirements for receptor transactivation functions. Mol Endocrinol. 1999;13(10):1672-85.

10. Carroll JS, Liu XS, Brodsky AS, Li W, Meyer CA, Szary AJ, et al. Chromosomewide mapping of estrogen receptor binding reveals long-range regulation requiring the forkhead protein FoxA1. Cell. 2005;122(1):33-43.

11. Zhao C, Gao H, Liu Y, Papoutsi Z, Jaffrey S, Gustafsson JA, et al. Genomewide mapping of estrogen receptor-beta-binding regions reveals extensive cross-talk with transcription factor activator protein-1. Cancer Res. 2010; 70(12):5174-83.

12. Maggiolini M, Bonofiglio D, Marsico S, Panno ML, Cenni B, Picard D, et al. Estrogen receptor alpha mediates the proliferative but not the cytotoxic dose-dependent effects of two major phytoestrogens on human breast cancer cells. Mol Pharmacol. 2001;60(3):595-602.

13. Sun PM, Gao M, Wei LH, Mustea A, Wang JL, Konsgen D, et al. An estrogen receptor alpha-dependent regulation of estrogen receptor-related receptor alpha in the proliferation of endometrial carcinoma cells. Int J Gynecol Cancer. 2006;16(Suppl 2):564-8.

14. Paruthiyil S, Parmar H, Kerekatte V, Cunha GR, Firestone GL, Leitman DC Estrogen receptor beta inhibits human breast cancer cell proliferation and tumor formation by causing a G2 cell cycle arrest. Cancer Res. 2004;64(1):423-8.

15. Strom A, Hartman J, Foster JS, Kietz S, Wimalasena J, Gustafsson JA. Estrogen receptor beta inhibits 17 beta-estradiol-stimulated proliferation of the breast cancer cell line T47D. Proc Natl Acad Sci U S A. 2004;101(6):1566-71.

16. Stanford JL, Szklo M, Brinton LA. Estrogen receptors and breast cancer. Epidemiol Rev. 1986;8:42-59.

17. Hayes EL, Lewis-Wambi JS. Mechanisms of endocrine resistance in breast cancer: an overview of the proposed roles of noncoding RNA. Breast Cancer Res. 2015;17:40.

18. Moy B, Goss PE. Estrogen receptor pathway: resistance to endocrine therapy and new therapeutic approaches. Clin Cancer Res. 2006;12(16):4790-3.

19. Luzhna $L$, Lykkesfeldt $A E$, Kovalchuk $O$. Altered radiation responses of breast cancer cells resistant to hormonal therapy. Oncotarget. 2015;6(3):1678-94.

20. Davies C, Pan H, Godwin J, Gray R, Arriagada R, Raina V, et al. Long-term effects of continuing adjuvant tamoxifen to 10 years versus stopping at 5 years after diagnosis of oestrogen receptor-positive breast cancer: ATLAS, a randomised trial. Lancet. 2013;381(9869):805-16.

21. Nicholson RI, Johnston SR. Endocrine therapy--current benefits and limitations. Breast Cancer Res Treat. 2005;93(Suppl 1):S3-10.

22. Johnston SR, Martin LA, Dowsett M. Life following aromatase inhibitors-where now for endocrine sequencing? Breast Cancer Res Treat. 2005; 93(Suppl 1):S19-25.

23. Osborne CK, Pippen J, Jones SE, Parker LM, Ellis M, Come S, et al. Doubleblind, randomized trial comparing the efficacy and tolerability of fulvestrant versus anastrozole in postmenopausal women with advanced breast cancer progressing on prior endocrine therapy: results of a north American trial. J Clin Oncol. 2002;20(16):3386-95.

24. Lykkesfeldt $A E$, Briand $P$. Indirect mechanism of oestradiol stimulation of cell proliferation of human breast cancer cell lines. Br J Cancer. 1986;53(1):29-35.

25. Lykkesfeldt AE, Madsen MW, Briand P. Altered expression of estrogenregulated genes in a tamoxifen-resistant and $\mathrm{ICI} 164,384$ and $\mathrm{ICI} 182,780$ sensitive human breast cancer cell line, MCF-7/TAM ${ }^{\mathrm{R}}$-1. Cancer Res. 1994; 54(6):1587-95.

26. Wang B, Chen J, Santiago FS, Janes M, Kavurma MM, Chong BH, et al. Phosphorylation and acetylation of histone $\mathrm{H} 3$ and autoregulation by early growth response 1 mediate interleukin 1 beta induction of early growth response 1 transcription. Arterioscler Thromb Vasc Biol. 2010;30(3):536-45.

27. Wang B, Li D, Sidler C, Rodriguez-Juarez R, Singh N, Heyns M, et al. A suppressive role of ionizing radiation-responsive miR-29c in the development of liver carcinoma via targeting WIP1. Oncotarget. 2015;6(12): 9937-50.

28. Musgrove EA, Sutherland RL. Biological determinants of endocrine resistance in breast cancer. Nat Rev Cancer. 2009;9(9):631-43.

29. Ring A, Dowsett M. Mechanisms of tamoxifen resistance. Endocr Relat Cancer. 2004;11(4):643-58.

30. Massarweh S, Osborne CK, Creighton CJ, Qin L, Tsimelzon A, Huang S, et al. Tamoxifen resistance in breast tumors is driven by growth factor receptor signaling with repression of classic estrogen receptor genomic function. Cancer Res. 2008;68(3):826-33.

31. Frogne T, Benjaminsen RV, Sonne-Hansen K, Sorensen BS, Nexo E, Laenkholm AV, et al. Activation of ErbB3, EGFR and Erk is essential for growth of human breast cancer cell lines with acquired resistance to fulvestrant. Breast Cancer Res Treat. 2009;114(2):263-75.

32. Thrane S, Lykkesfeldt AE, Larsen MS, Sorensen BS, Yde CW. Estrogen receptor alpha is the major driving factor for growth in tamoxifen-resistant breast cancer and supported by HER/ERK signaling. Breast Cancer Res Treat. 2013;139(1):71-80.

33. Nicholson RI, Hutcheson IR, Britton D, Knowlden JM, Jones HE, Harper ME, et al. Growth factor signalling networks in breast cancer and resistance to endocrine agents: new therapeutic strategies. J Steroid Biochem Mol Biol. 2005;93(2-5):257-62.

34. Masamura S, Santner SJ, Heitjan DF, Santen RJ. Estrogen deprivation causes estradiol hypersensitivity in human breast cancer cells. J Clin Endocrinol Metab. 1995:80(10):2918-25.

35. Martin LA, Farmer I, Johnston SR, Ali S, Dowsett M. Elevated ERK1/ERK2/ estrogen receptor cross-talk enhances estrogen-mediated signaling during long-term estrogen deprivation. Endocr Relat Cancer. 2005;12(Suppl 1):S75-84.

36. Martin LA, Farmer I, Johnston SR, Ali S, Marshall C, Dowsett M. Enhanced estrogen receptor (ER) alpha, ERBB2, and MAPK signal transduction pathways operate during the adaptation of MCF-7 cells to long term estrogen deprivation. J Biol Chem. 2003;278(33):30458-68.

37. Elias D, Vever H, Lænkholm AV, Gjerstorff MF, Yde CW, Lykkesfeldt AE, et al. Gene expression profiling identifies FYN as an important molecule in tamoxifen resistance and a predictor of early recurrence in patients treated with endocrine therapy. Oncogene. 2015;34(15):1919-27.

38. Thrane S, Pedersen AM, Thomsen MB, Kirkegaard T, Rasmussen BB, DuunHenriksen AK, et al. A kinase inhibitor screen identifies Mcl-1 and aurora kinase a as novel treatment targets in antiestrogen-resistant breast cancer cells. Oncogene. 2015;34(32):4199-5210.

39. Lin $X$, Li J, Yin G, Zhao Q, Elias D, Lykkesfeldt $A E$, et al. Integrative analyses of gene expression and DNA methylation profiles in breast cancer cell line models of tamoxifen-resistance indicate a potential role of cells with stemlike properties. Breast Cancer Res. 2013;15(6):R119.

40. Oldham WM, Hamm HE. Heterotrimeric G protein activation by G-proteincoupled receptors. Nat Rev Mol Cell Biol. 2008;9(1):60-71.

41. Block H, Stadtmann A, Riad D, Rossaint J, Sohlbach C, Germena G, et al. Gnb isoforms orchestrate a signaling pathway comprising Rac1 and Plcbeta2/3 leading to LFA-1 activation and neutrophil arrest in vivo. Blood. 2016;127(3):314-24.

42. Soong BW, Huang YH, Tsai PC, Huang CC, Pan HC, Lu YC, et al. Exome sequencing identifies GNB4 mutations as a cause of dominant intermediate Charcot-Marie-tooth disease. Am J Hum Genet. 2013;92(3):422-30.

43. Baets J, De Jonghe P, Timmerman V. Recent advances in Charcot-Marietooth disease. Curr Opin Neurol. 2014;27(5):532-40.

44. Riemann K, Struwe H, Alakus H, Obermaier B, Schmitz KJ, Schmid KW, et al. Association of GNB4 intron-1 haplotypes with survival in patients with UICC stage III and IV colorectal carcinoma. Anticancer Res. 2009;29(4):1271-4.

45. Riemann K, Struwe H, Eisenhardt A, Obermaier B, Schmid KW, Siffert W. Characterization of intron-1 haplotypes of the $\mathrm{G}$ protein beta 4 subunit gene--association with survival and progression in patients with urothelial bladder carcinoma. Pharmacogenet Genomics. 2008;18(11):999-1008.

46. Umar A, Kang H, Timmermans AM, Look MP, Meijer-van Gelder ME, et al. Identification of a putative protein profile associated with tamoxifen therapy resistance in breast cancer. Mol Cell Proteomics. 2009;8(6):1278-94.

47. Ryoo HD, Bergmann A. The role of apoptosis-induced proliferation for regeneration and cancer. Cold Spring Harb Perspect Biol. 2012;4(8):a008797.

48. Dichtel-Danjoy ML, Ma D, Dourlen P, Chatelain G, Napoletano F, Robin M, et al. Drosophila p53 isoforms differentially regulate apoptosis and apoptosisinduced proliferation. Cell Death Differ. 2013;20(1):108-16.

49. Mollereau B, Perez-Garijo A, Bergmann A, Miura M, Gerlitz O, Ryoo HD, et al. Compensatory proliferation and apoptosis-induced proliferation: a need for clarification. Cell Death Differ. 2013;20(1):181.

50. Murga C, Laguinge L, Wetzker R, Cuadrado A, Gutkind JS. Activation of Akt/ protein kinase B by $\mathrm{G}$ protein-coupled receptors. A role for alpha and beta gamma subunits of heterotrimeric $G$ proteins acting through phosphatidylinositol-3-OH kinasegamma. J Biol Chem. 1998;273(30):19080-5.

51. Wang B, Hendricks DT, Wamunyokoli F, Parker MI. A growth-related oncogene/CXC chemokine receptor 2 autocrine loop contributes to cellular proliferation in esophageal cancer. Cancer Res. 2006;66(6):3071-7. 
52. Lim S, Kaldis P. Cdks, cyclins and CKIs: roles beyond cell cycle regulation. Development. 2013;140(15):3079-93.

53. Knoblich JA, Sauer K, Jones L, Richardson H, Saint R, Lehner CF. Cyclin E controls $S$ phase progression and its down-regulation during Drosophila embryogenesis is required for the arrest of cell proliferation. Cell. 1994;77(1):107-20.

54. Niehrs C, Acebron SP. Mitotic and mitogenic Wnt signalling. EMBO J. 2012; 31(12):2705-13.

55. Ogura Y, Sakaue-Sawano A, Nakagawa M, Satoh N, Miyawaki A, Sasakura Y. Coordination of mitosis and morphogenesis: role of a prolonged G2 phase during chordate neurulation. Development. 2011;138(3):577-87.

56. Cheng A, Solomon MJ. Speedy/Ringo C regulates $S$ and G2 phase progression in human cells. Cell Cycle. 2008;7(19):3037-47.

\section{Ready to submit your research? Choose BMC and benefit from:}

- fast, convenient online submission

- thorough peer review by experienced researchers in your field

- rapid publication on acceptance

- support for research data, including large and complex data types

- gold Open Access which fosters wider collaboration and increased citations

- maximum visibility for your research: over $100 \mathrm{M}$ website views per year

At BMC, research is always in progress.

Learn more biomedcentral.com/submissions 